\title{
Overview and Prospect of Construction Labor Productivity
}

\author{
Yishu Shang ${ }^{1, a^{*}}$ and Dong Zhai, b \\ ${ }^{1}$ College of Civil Engineering and Architecture, Zhejiang University, China

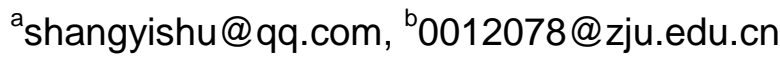

Keywords: Construction; Labor productivity; Industry level; Activity level.

\begin{abstract}
The paper classifies construction labor productivity from macro industry level to micro activity level and combs the research status at home and abroad of it, including the definition, calculation, evaluation system, affecting factors and affecting capacities. These help researchers to have a comprehensive and three-dimensional understanding of construction labor productivity and lay a solid foundation for the future theoretical studies and practical studies on it. At last, 4 future research topics are suggested.
\end{abstract}

\section{Introduction}

Chinese economy is experiencing a new change that the high-flying days have hit a major speed bump. Meanwhile, as one of the five pillar industries in China, construction industry has also slowed down the growing pace. The total output value of construction industry rose $10.2 \%$ in 2014 , the lowest for over 16 years.

In a long time in the past, sustained fixed assets investment and abundant labor force have made great contribution to the rapid development of construction. But the future expansion of investment scale is more and more limited and the population is aging fast. The whole construction industry is losing its original momentum. The strongest evidence is that while the total output value of construction in-creased rapidly year by year, the labor productivity increased slowly (Fig. 1). Therefore, improving the quality and efficiency of production, especially the construction labor productivity, are keys to promote the economic profit of building enterprises and to ensure the sustained stable growth of the construction industry. This is also a necessary transition requirement for construction development, from an extensive growth mode to an intensive one.

- Total Output Value of Construction (relative value)

- Labor Productivity in Terms of Total Output Value of Construction (relative value)

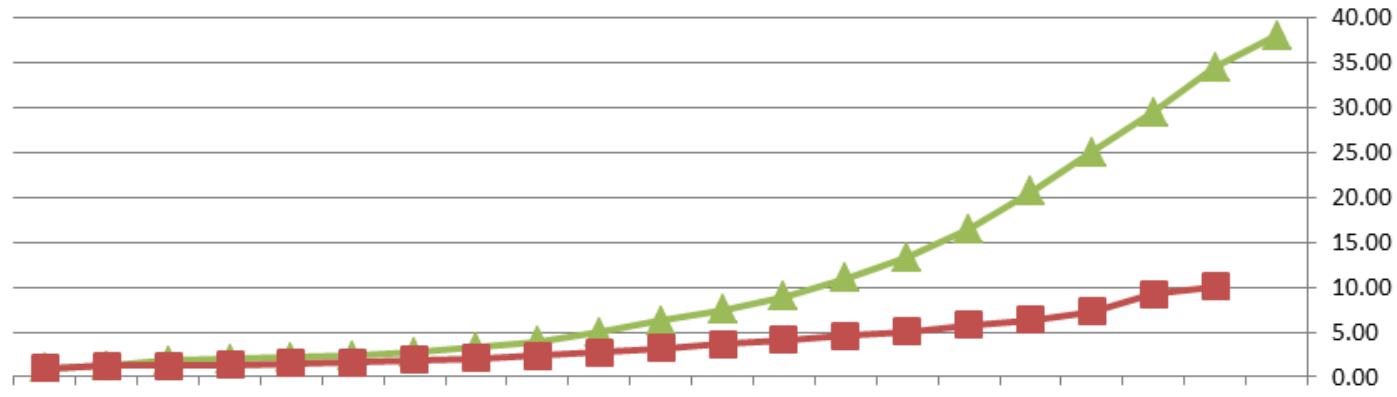

199419951996199719981999200020012002200320042005200620072008200920102011201220132014

Figure 1. The relative change of total output value and labor productivity of construction industry in China. The relative change is calculated by dividing the value in the other year by the corresponding value in 1994 which signed as 1. Data sources: http://data.stats.gov.cn/.

\section{Reviews of Development in Construction Labor Productivity}

This paper focuses on construction labor productivity, combines the construction industry's characteristics and combs relevant researches into 4 categories. As domestic concerned researches 
start late, more foreign researches are added. This also helps to find the differences between foreign and domestic researches in this field.

Definition, Calculation and Evaluation. This category includes an understanding of the meaning of labor productivity, calculation methods and the evaluation system.

Labor productivity is the fruits of labor created per unit time or the labor time spent per unit product. The more fruits of labor created per unit time and the less labor time spent per unit product, the higher the labor productivity.

As to construction labor productivity, the basic representation is the ratio of the construction products output to the labor input. It can be classified in-to physical labor productivity and value labor productivity, according to the different forms of output indicators. The output of physical labor productivity is expressed by the quantities of works, measured in square meters, cubic meters or tons; the output of the value labor productivity is expressed by the magnitude of value, measured in monetary unit, which is more widely used. The input is usually expressed by the workforce or the labor time.

In this paper, two types of labor productivity are separately further classified into the macro industry labor productivity and the micro activity one. The former shows the average labor productivity of the construction industry and gets data from National Statistics; the latter shows the individual labor productivity of construction activities. Table 1 summarizes the calculation methods of different forms of construction labor productivity.

Table 1 Calculation methods of construction labor productivity

\begin{tabular}{|c|c|c|}
\hline Category & Level & Formula \\
\hline \multirow{4}{*}{$\begin{array}{l}\text { Physical } \\
\text { labor } \\
\text { productivity }\end{array}$} & \multirow{2}{*}{ Industry } & Floor Space Completed $\left(\mathrm{m}^{2}\right)$ \\
\hline & & Number of Persons Employed (person) \\
\hline & \multirow{2}{*}{ Activity } & $I P=\frac{\text { Physical Output (units such as } m, m^{2}, m^{3} \text { and } t \text { ) }}{2}$ \\
\hline & & Labor Time (man-hour or man-day) [2-6] \\
\hline \multirow{8}{*}{$\begin{array}{l}\text { Value } \\
\text { labor } \\
\text { productivity }\end{array}$} & \multirow{6}{*}{ Industry } & $=\frac{\text { Total Output Value of Construction (monetary unit) }}{}$ \\
\hline & & Number of Persons Employed (person) \\
\hline & & Value - Added of Construction (monetary unit) \\
\hline & & Number of Persons Employed (person) $\quad[1,8-12]$ \\
\hline & & Value - Added of Construction (monetary unit) \\
\hline & & Labor Time (man-hour or man-day) \\
\hline & \multirow{2}{*}{ Activity } & $L P \approx$ Labor Cost Per Physical Output (monetary unit) \\
\hline & & Labor Cost Per Day (monetary unit) \\
\hline
\end{tabular}

Obviously, industry labor productivity is affected by the uncertainty of input and output in the statistical process, so the final computed results have limitations in some degree. Rojas and Aramvareekul compute both the industry and activity labor productivity of construction labor productivity in America from 1979 to 1998 but get inconsonant trends of productivity [13]. It should also be noted that as the interest bodies tend to be diversified and the specialized subcontracting becomes more common, the output and workforce of subcontracted construction teams can't be forgotten to ensure the accuracy [15].

Activity labor productivity also has some defects and can only present individual labor productivity for one construction activity. So researchers try to design and develop a comprehensive evaluation sys-tem combined with activity labor productivity to uniform measurement. Park et al. provide a construction productivity metrics system, which contains 56 data elements grouped into 7 categories, to benchmark construction productivity and help compare productivity in different regions 
or for different construction enterprises [16]. Based on the principle of lean construction, Abdel-Razek and Abdel-Hamid develop a similar metrics system including three types of variables: damage coefficient, performance rate and project management [17].

As the information technology has been increasingly widely used in our life and work, researchers also apply it into the statistics and measurement of construction labor productivity. Song and AbouRizk use the artificial neural network and the discrete event simulation to develop a project labor productivity model which can rationally set project scheduling through historical productivity data [18]. Chen design an acquisition system of construction worker productivity data based on ZigBee network, which realizes real-time acquisition and analysis of on-site construction workforce's productivity and also provides data to compile construction plans and quota [19].

Characterization and Comparison. This category includes the development law and characteristics of the overall construction labor productivity in a country or region and the differences among countries or industries.

Characterization Study. Kazaz and Ulubeyli visit 32 Turkish building firms, collect labor productivity data from 82 construction activities and apply T-test to analyze the development of Turkish construction labor productivity [5]. By contrast, statistical data is more suitable for characterization study. Wang and Yuan use statistical data in 8 regions in China from 2000 to 2004 and find an increasing trend of domestic construction labor productivity [20]. Similarly, Tan and Yuan analyze the national construction labor productivity in China based on statistical data from 1997 to 2007 [11].

Comparison Study. Some domestic scholars try to find the differences of construction labor productivity among countries or industries. Jiang compares the project cost in Hong Kong and Shenzhen and points out that the development of construction labor productivity on the mainland still has great potential [14]. Sha uses 1900's data of four provinces in East China and compares the level and benefits of labor productivity in different development modes [1]. Wu et al. introduce purchasing power parity theory, analyze the productivity gap between construction and other industries in China and propose more investments in construction [12]. Zhao and Shi indicate that domestic construction labor productivity in 1900s is less than one-third of the domestic gas or power industry's, and is equivalent to $1.25 \%$ of Japanese construction's [21]. According to the above studies, Chinese construction has experienced a rapid growth period, but the overall construction productivity still has great room to improve.

Affecting Factors. With construction labor productivity as the dependent variable, researchers are trying to find the affecting factors of construction labor productivity. These studies are of great significance in reality and can actually help building firms to improve labor productivity and economy benefits. So a lot of domestic and foreign scholars are attracted into this type of studies. This section classifies them from industry level and activity level as before.

Industry Level. From the industry level, researchers study factors affecting labor productivity of the whole construction industry or building firms. Allen points out that the main course of the fall in American construction productivity is decreased skilled labor and the shift in construction product's demand from commercial, industrial and institutional building products to the single-family villas [8]. Other reasons such as the decline in the number of employees, capital-labor ratio, percent union and the average age of workers also can't be ignored. Arditi and Mochtar survey the American construction companies in the top 400 and find the importance of cost management, schedule management, design optimization, manpower training and quality management for improving construction labor productivity [2]. Rojas and Aramvareekul enlarge the research to owners, general contractors, electrical contractors, mechanical contractors and engineering consultants, and indicate that internal factors such as management skills and human recourses have more significant impacts on labor productivity than external factors such as investments and policies [22].

Domestic scholars mostly concern about the influences of capital, labor and technology progress on construction labor productivity. Ye apply C-D production function and the simple linear regression and finds the technology progress's main contribution to construction labor productivity [23]. She 
also notes that a wage increase is also a great motivator. Liu and Qin give detail and quantitative analysis of the close relationship between wages and construction labor productivity, that one yuan of the wage increase can create 1.45 yuan in productivity growth [10]. This viewpoint is also supported by Yang and Guo based on VAR model and she indicates current labor prices have a bigger impact on productivity than quota prices [7]. Besides, different factors have different influences in different stages of development and Guo proposes an upgrading way to enhance our construction labor productivity, which is from labor input to capital deepening to technology progress [9].

Activity Level. Due to the practical value of the conclusions for building firms, activity productivity attracts more scholars to study its affecting factors. Sonmez and Rowings use regressions and the neural net-work to develop a labor productivity model, which can applied to concrete work and formwork and quantify different factors' influences on labor productivity based on data from 8 building projects [24]. Kadir et al. visit contractors, developers and consultants and get the five most important affecting factors of on-site productivity from 50 prepared factors, which are on-site material shortage, engineering change requests, drawings delay and on-site management [25]. From the perspective of construction workers, Dai et al. find that influences of consumables, materials, drawings and machines are most significant for their own productivity [26].

In recent years, scholars are more interested in some new and interesting factors. Mohamed and Srinavin build a predicted mean vote (PMV) model to forecast the changes of construction labor productivity with the environment temperature [6]. And the most popular researching topic is about influences of the high technology on construction labor productivity, represented by information technology. Grau et al. compare the productivity differences between traditional material management and automated material management with updated in-formation technology [4]. The result indicates that automated management significantly improves labor productivity. Goodrum et al. study the relationship between changes in material technology and construction productivity and find that the reduction in the unit weight of a material is the biggest contributor to improving labor productivity [3]. Similarly, Zhai et al. show that the application of information technology does improve labor productivity based on data from concrete work, steel structural work, electrical work and piping work [27].

Affecting Capacities. With construction labor productivity as the independent variable, researchers are trying to find its influences on others, including performance, safety, wages and quality. Abdel-Razek and Abdel-Hamid use data from masonry activities on eleven building projects in Egypt and the result indicates that the variability in daily productivity can be a delineator between good and poorly performing projects [17]. Zhou compares labor productivity's contribution on real wages among industries and finds that there is less contribution in labor-intensive industries represented by construction than in knowledge-intensive industries represented by high technology [28]. Wang analyzes the relationship between Chinese construction labor productivity and safety production and concludes that accident death rate decreases with the increasing of labor productivity, which challenges the long-held perception that safety input and productivity profit are incompatible [29].

In addition, construction labor productivity is also used as an index to evaluate the international competitiveness of Chinese construction, the regional construction development, and economic performance of construction enterprises and so on [30-32].

\section{Future Research Prospects}

More Accurate Industry Studies and Deeper Activity Studies. Industry studies help researchers to understand the national or regional construction labor productivity in a whole. They usually have high requirements on the accuracy and processing of data. For example, considering inflation, it is necessary to make adjustments to construction value added. But due to the diversification and complicacy of construction products, there is no standard and applicable price index to assist researches. Thus, the results may be affected by the choice of the deflator [33]. 
Activity studies are more pertinence to construction activities and projects, so it is more convenient and accurate to collect labor productivity data. They also provide a more intuitive perspective to observe the actual improvement of construction labor productivity and practical suggestions for building firms. But it is hard to grasp the national or regional productivity through the labor productivity of frag-mental construction activities.

In general, the domestic and foreign researches on construction labor productivity incarnate different depth and width. Foreign researches, mainly at the activity level, pay more attention to the practice value of the research process and results. Many newest and hottest topics are also added into researches, such as environment and internet applications. By contrast, domestic researches are conventional, based on comprehensive analysis of macro data. So more accurate industry studies and deeper activity studies are directions for future researches.

The Relationship of Technology Progress, Cost Savings and Productivity Growth. Technology progress has significant effects on productivity growth, but the speedy development of Chinese construction and huge demands of construction products can not wait building firms to innovate on technology. Meanwhile, the existing extensive production model and cheap labor fully adapt to this fast-developing society, and whether contractors or developers are not willing to bear the risk of developing and adopting new techniques. However, with the spreading labor shortage and diminishing "demographic dividend", it is time to find the best equilibrium point between technology progress, cost savings and productivity growth and reduce the concerns of the enterprises.

Differences between Quota Productivity and Jobsite Productivity. In the actual construction, the labor productivity of jobsite workers must be affected by some subjective or objective factors and diverge from quota. Large deviations may delay the project and multiply costs, so it is worthy to study differences between quota productivity and jobsite productivity and find factors significantly affecting jobsite labor productivity. This can help contractors to avoid disadvantages during construction and take targeted safeguards to ensure the schedule.

New Building Industrialization and Labor Productivity. New building industrialization is the trend of the future construction industry, including standardized design, factory production, assembly construction, and decoration support and information management. It can improve the quality and profits of the construction and achieve energy saving and emission reduction. Meanwhile, it will provide more jobs for mi-grant workers promote their career transformation to industrial skilled workers and propel the urbanization process. The detailed analysis of the relationship between new building industrialization and labor productivity can help encourage contractors to at-tempt industrialized construction and improve labor productivity.

\section{References}

[1] K.X. Sha: Tiedao Gongcheng Qiye Guanli, (2006) No.01, p.12. (In Chinese)

[2] D. Arditi and K. Mochtar: Construction Management \& Economics, Vol. 18 (2000) No.1, p.15.

[3] P. M. Goodrum, D. Zhai and M. F. Yasin: Journal of Construction Engineering and Management, Vol. 135 (2009) No.4, p.278.

[4] D. Grau, C. H. Caldas, C. T. Haas, P. M. Goodrum and J. Gong: Automation in Construction, Vol. 18 (2009) No.7, p.903.

[5] A. Kazaz and S. Ulubeyli: Building and environment, Vol. 39 (2004) No.1, p.93.

[6] S. Mohamed and K. Srinavin: International Journal of Industrial Ergonomics, Vol. 35 (2005) No.4, p.345.

[7] X. Yang and J.J. Guo: Journal of Engineering Management, (2014) No.05, p.83. (In Chinese)

[8] S. G. Allen: (1985).

[9] J.L. Guo: Research on Labor Productivity in Construction Industry of China (MS., Chang'an 
University, China, 2014). (In Chinese)

[10] K.J. Liu and D.W. Qin: Co-Operative Economy \& Science, (2010) No.09, p.30. (In Chinese)

[11]W. Tan and J. Yuan: Modern Economic Information, (2009) No.09, p.63. (In Chinese)

[12]W.X. Wu, Q.M. Li, X.G. Li and Y.Q. Gu: Journal of Civil,Architectural \& Environmental Engineering, (2007) No.06, p.136. (In Chinese)

[13]E. M. Rojas and P. Aramvareekul: Journal of Construction Engineering and Management, Vol. 129 (2003) No.1, p.41.

[14]Y.B. Jiang: Building Construction, Vol. 26 (2004) No.5, p.457. (In Chinese)

[15]F. Huang and Z.Q. Liu: Tongji Yu Zixun, (2008) No.04, p.32. (In Chinese)

[16]H. Park, S. R. Thomas and R. L. Tucker: Journal of Construction Engineering and Management, Vol. 131 (2005) No.7, p.772.

[17]R. H. Abdel-Razek and M. Abdel-Hamid: International Journal of Project Management, Vol. 25 (2007) No.2, p.189.

[18]L. Song and S. M. Abourizk: Journal of Construction Engineering and Management, Vol. 134 (2008) No.10, p.786.

[19]J.J. Chen: Design of Productivity Data Collection and Analysis Systems Based on Zigbee (MS., Central South University, China, 2014). (In Chinese)

[20] J.Y. Wang and H.P. Yuan: Construction Economy, (2006) No.09, p.5. (In Chinese)

[21] Y. Zhao and J. Shi: Sci-Tech Information Development \& Economy, (2010) No.30, p.165. (In Chinese)

[22]E. M. Rojas and P. Aramvareekul: Journal of Management in Engineering, Vol. 19 (2003) No.2, p.78.

[23] Y. Yuan: Journal Of Shandong University Of Architecture And Engineering, Vol. 19 (2004) No.1, p.32. (In Chinese)

[24]R. Sonmez and J. E. Rowings: Journal of Construction Engineering and Management, Vol. 124 (1998) No.6, p.498.

[25]M. R. A. Kadir, W. P. Lee, M. S. Jaafar, S. M. Sapuan and A. A. A. Ali: Structural Survey, Vol. 23 (2005) No.1, p.42.

[26]J. Dai, P. M. Goodrum and W. F. Maloney: Journal of Construction Engineering and Management, Vol. 135 (2009) No.3, p.217.

[27]D. Zhai, P. M. Goodrum, C. T. Haas and C. H. Caldas: Journal of Construction Engineering and Management, Vol. 135 (2009) No.8, p.746.

[28] J. Zhou: Productivity Research, (2009) No.14, p.22. (In Chinese)

[29]Z. X. Wang: Data analysis and countermeasures research of building softy of China (MS., South China University of Technology, China, 2010). (In Chinese)

[30] S.M. Gong and H. Cheng: Construction Economy, (2000) No.01, p.35. (In Chinese)

[31]J.Y. Wang and H.P. Yuan: Journal of Shenzhen University Science and Engineering, (2007) No.04, p.373. (In Chinese)

[32] J.S. Fan: China Civil Engineering Journal, (2011) No.10, p.124. (In Chinese)

[33]P. Teicholz, P. M. Goodrum and C. T. Haas: Journal of Construction Engineering and Management, Vol. 127 (2001) No.5, p.427. 